\title{
Dramatic images of man in medieval drama and Shakespeare
}

\section{Peter Happé}

\section{(2) OpenEdition}

\section{Journals}

\section{Electronic version}

URL: http://journals.openedition.org/shakespeare/911

DOI: 10.4000/shakespeare.911

ISSN: 2271-6424

\section{Publisher}

Société Française Shakespeare

\section{Printed version}

Date of publication: 1 November 2002

Number of pages: 71-93

\section{Electronic reference}

Peter Happé, "Dramatic images of man in medieval drama and Shakespeare », Actes des congrès de la Société française Shakespeare [Online], 19 | 2002, Online since 01 November 2007, connection on 30 April 2019. URL : http://journals.openedition.org/shakespeare/911 ; DOI : 10.4000/shakespeare.911 


\section{S H A K E S P E A R E \\ \& L E M O Y E N - Â G E}

Société Française Shakespeare

Actes du Congrès de 2001

* * *

Textes réunis et présentés par

Patricia DORVAL

publiés sous la direction de Jean-Marie MAGUIN 


\section{R A M A T I C I M A G E S OF M A N I N M E D I E V A L D R A M A N D \\ S H A K E S P E A R E}

In this paper I should like to bring together some aspects of medieval drama and the work of Shakespeare, bearing in mind that the continuity of ideas and, to some extent, of theatrical practices from medieval times remains somewhat undervalued. To trace such continuity is not to deny that there are significant differences, but it is desirable to be sensitive to both, so that our perception of each may be the more sustainable. The medieval plays I shall consider here are substantially from the fifteenth century : The Castle of Perseverance, Mankind, Wisdom, and L'Omme Pecheur, but The World and the Child, which for my purposes is very much in the same vein, may not have been written much earlier than 1508 '. I have selected Richard II, Hamlet, and King Lear for the purpose of comparison : received opinion suggests that these were written between 1597 and 1605, though the recent discussions of the revisions to King Lear for the First Folio text may mean that some of the material in this play is somewhat later.

My term «dramatic image» may need some explanation. I am using it so as to suggest that in these plays there may be ideas about, and representations of aspects of Man, which can be found in both groups. In this paper I have normally used «Man» generically. This usually has the 
implication of all human beings, but a gendered reading of these plays would have to deal separately with Woman. For the moralities, I have occasionally used the specific name in each play: Humanum Genus in Castle of Perseverance; Mankind in Mankind; Anima, who is actually female, in Wisdom. The protagonist of The World and the Child has a number of names, progressively Infans, Wanton, Lust Lyking, Manhode, Shame, and Age ; and similarly L'Adolescent becomes L'Omme Pecheur or Pecheur. But one should add that because these are plays, much of what they comprise concerns non-linguistic systems, most particularly in the visual medium. It follows therefore that some dramatic images, whilst they may be capable of being realised in words, will also have a powerful visual dimension. As an example of this we may cite parts of the third Act of King Lear where the visual interaction, no doubt emphasized by all sorts of directorial devices, may bring a sharp contrast between the figures of the maddened Lear, his Fool, and the Poor Tom. However this may be staged, there is no doubt that the text requires a visual juxtaposition of these three figures, together with a series of dynamic modifications of the relationships between them. In other words these texts, both medieval and Shakespearean, work as theatrical documents, rather than as purely literary ones. Beyond this, however, the physical conditions of medieval staging were different from Shakespeare's ; and indeed these latter were determined by all sorts of external factors, including the enormous changes in the status and working practices of dramatic companies through the fifteenth and sixteenth centuries. This means that dramatic images would have functioned differently in their different theatrical contexts. Nevertheless it is my main suggestion that there is some continuity in concepts about Man and the presentation of them in theatrical terms, and hopefully the following consideration of these may illuminate both sets of plays. To take a fairly pragmatic view, these images were a valuable resource in both sorts of theatre.

In the group of medieval plays chosen here there is a great deal of correspondence in general terms, and this reflects the universality of medieval Christian culture, as well as of staging practice. I have been particularly interested to find that there are many aspects of L'Omme Pecheur which can be found similar to the English morality plays. This is valuable because there are really not so many English morality plays extant to give the basis for general conclusions about them, whereas the French corpus is rather larger and more varied. In the light of this we may usefully give some consideration to allegory.

Allegorical drama depends upon a number of figures which embrace a narrative. Among others these may include a journey, a battle, or the 
coming of death. Thus the image of pilgrimage is common, and so are war and physical conflict. The pilgrimage may be from birth to death, as in The World and the Child, where, in a relatively short play designed for only two actors, the human protagonist moves through birth, childhood, youth, maturity and age. The advantage of this structure is that it enables the protagonist to meet characters good and bad, who may help or hinder, and encounter events which mark crises in the journey. An instance of this occurs when Manhode encounters seven kings, who turn out to be the Deadly Sins. His acceptance and subsequent rejection of them form a large part of the action. Such is the conception and organisation of morality plays that all the characters met and all the incidents encountered are part of the ultimate purpose of salvation. Frequently there are crucial episodes where a number of different allegorical structures are brought to bear. Thus in The World and the Child Man meets the Sins, embodies in himself the ancient configuration of the Ages of Man, and is ultimately rescued by Perseverance. The art of allegory in the plays may well be seen to comprise a skill in arranging such structural interactions : Helmich called this the «superposition des motifs» (1981, p. 216). The effect of this process is that we are invited to respond not to one allegory but to a multivalent interplay, which, though it defies verisimilitude, is usually firmly arranged according to an ethical and salvation-orientated framework.

The Castle of Perseverance, the longest extant English morality, shows man moving from his youth into manhood, on towards death and beyond. Because of the survival of a stage diagram, and because of the nature of the plot as it unfolds, it is apparent that he is threatened by three enemies, the World, the Flesh and the Devil, each of whom attack him in turn. Between them, they control all the Deadly Sins, and these form the antagonists in the siege which develops when Man takes refuge in the Castle with the Seven Virtues. His arrival there, however, is prefaced by an important preliminary sequence in which he must fully encounter the World. He is taken to World's scaffold by the Bad Angel, but, as we shall see, there is an inevitability about this since all men must go to the World in order to live. This makes the World both an enemy and a necessary constituent of existence : not easy to reconcile logically, yet rich in symbolic impact. In this case, World leads Man into evil ways from which he is rescued by Shrift and Confession and taken to the Castle. Man's submission to the power and influence of the World is visually signified by his ascent to World's scaffold and his later descent from it (stage directions at 1.614 and 1.1445). The ensuing siege of the Castle is highly spectacular, and it appears from the diagram that the play was constructed to make the most of the inherent theatricality of this episode. 
One stage direction reads : tunc pugnabunt diu and at this point at least twenty actors are needed, without counting extras. However the defence by the Virtues prevails, and the unsuccessful besieging Vices are consequently punished by their masters with a beating.

It is worth taking note of the question whether the play was ever produced. It required a large arena with a space for large-scale movement and processions, the central castle, five scaffolds, possibly a moat and bridge. The practical arrangements are demanding and the organisation of a performance complex. It is not easy to see where the necessary resources might have come from, but the point arising is that even if it were never performed, the play in the manuscript gives us much information about the dramatic imagination of the author. This potential must include the images we have been discussing. The style of the mise-en-scène has similarities with L'Omme Pecheur and the mystères. The text of L'Omme Pecheur, a printed copy, claims that the play was indeed performed at Tours in 1494.

From this sequence we see that Man is vulnerable to his enemies, but supported by Virtues who may ensure his salvation. To this extent he has to run the gauntlet of threatening external forces. But the images of Man in other plays stress his lowly origins and his vulnerability. L'Omme Pecheur begins with Man's creation, personifying La Terre and her daughter, Le Lymon (Mud), who make up his body. In Mankind there is a reference to flesh as a «stynkynge dungehyll». Man's nakedness is presented in Castle of Perseverance, The World and the Child, and L'Omme Pecheur; Worlde and Monde provide clothing and livelihood. Manhode says «The Worlde fyndeth me all thynge / And dothe me grete seruyse» (1. 516-7). But there is also a moral weakness in Man, no doubt associated with original sin and the corruption of the flesh. In The World and the Child, Manhode says he was «goten in game and in grete synne» (1. 30). Wisdom tells Anima «... ye be dysvyguryde be hys synne» (1. 117 : i.e. Adam's). Man's frailty appears more than once in L'Omme Pecheur and Lucifer comments upon this as he prepares an assault in Wisdom. Man's fate thereafter is that he must work, but there is still the possibility that through honest labour salvation may be achieved. This underpins the main plot of Mankind, which turns on how the protagonist may succumb to idleness and so be vulnerable to temptation towards the worldly frivolities embodied in Newguise, Nowadays and Nought.

But the paradox frequently remarked is that Man is also admirable «of condycyon contrarye» says Mankind (1.195), and the two aspects are 
«euer querulose». Fragility is contrasted with beauty, and in L'Omme Pecheur it is made clear that Man is made in God's image :

fragille est il, mortel et corruptible

puis quen luy est beaulte imcomparable. (aiiii)

The theme is varied in Wisdom, where Anima, the lover of Christ, is described by Wisdom :

Yt ys the ymage of Gode that all began

And not only ymage, but hys lyknes ye are. (1. 103-4)

At least until Adam :

Off all creaturys the fayrest ye ware. (1. 105-6)

Even Lucifer admits Man is admirable :

That Soule Gode made incomparable

To hys lyknes most amyable. (1. 535-6)

Within the soul, however, there may be division, for Anima has two components, Sensuality and Reason, and these two are «Blake and wyght» (1. 151). This antipathy may be perceived externally, for Raison and Sensualite play a great part in the fortunes of L'Omme Pecheur. Dieu sends him Franc Arbitre, Charite and Raison, and it is Raison who perceives L'Adolescent's creation in God's own image :

Le roy du firmament

Qui te fist proprement

A sa propre figure... (aviiv)

In relation to the allegory of the World, Sensualite blames Raison for limiting the control which Monde exercises.

There are occasions where Good and Bad Angels are opposed over Man's salvation, but the remedies for his evils and for his vulnerability often had a more specific dramatic imagery. We have noted that for a time Man is secure in the Castle of Perseverance. Le Pecheur receives solace in the Arbre des Vertus, and this is apparently a visual contrast with the Arbre des Vices which he has previously ascended. He is also supported by Entendement and Conscience. Both these operate in tandem with Franc Arbitre, who allows le Pecheur to choose freely between good and bad. In 
Castle of Perseverance Man is supported by Confession and there is a dramatic moment at his death when he succeeds, just in time, in appealing for mercy. This cry is heard in heaven and his plea is then carried forward into the Trial in Heaven, where the Four Daughters of God discuss his fate and he is forgiven at the last. Again there is a strong sense that one allegorical structure is made to lead into another, as the dramatist sets out the way to salvation and the essential constituents of it. One should not overlook the theatrical effectiveness of this transition at the death of Humanum Genus. He dies in pitiful and terrible circumstances. He loses all his goods and property as his body fails him, and he is mocked by an evil boy, a total stranger called I-wot-neuere-whoo (1. 2967-8). It is a descent into horror and the loss of identity, as everything is swept away. But the Soul survives in the theatrical form of a boy who emerges from a chest at the foot of Man's bed, and it is he, with his appeal for mercy, who is taken into the trial and thence into God's scaffold.

The allegorical structures revealing various images of Man, which we have discussed so far, are supplemented by a number of other devices. One of these is the threat presented by folly. In Castle of Perseverance Stulticia is one of the servants of the World, and as such he is seen as unremittingly evil. He indicates the universality of folly and its threat:

Thorwe werldys wysdom of gret degre

Schal neuere man in werld moun wende

But he haue help of me

That am Foly fer and hende.

He must hangyn on my hoke. (1. 508-12)

He offers to Humanum Genus a foolish indulgence in worldly pleasures, including riches and the fashionable life. In this he takes up some of the ground occupied by Newguise, Nowadays and Nought in Mankind. Though these three characters are not named fools, they offer a quite pointless and selfish indulgence in worldly affairs, and in doing so, like Stulticia, they contribute to the exposure and downfall of Man. There is always the possibility that folly is within Man himself, and likely to be activated by temptation. In The World and the Child where the character of Folye takes a leading part in the disgrace of Manhode. Here he makes a lively antagonist in a play which was probably written for only two actors constantly sparking off one another ${ }^{2}$. He boasts and plays the fool; not revealing his true identity, he tempts Manhode into a fight. His explanations of his own significance are rich, varied and far reaching through different levels of society. It turns out that he has affinities with 
lords, lawyers, and those who haunt the stews, and he admits that he is close to the World :

For Folye is felowe with the World

And gretely beloued with many a lorde,

And yf ye put me out of your warde

The Worlde ryght wroth wyll be. (1.618-21)

He claims that he is most at home in London, «my chefe dwellynge» (1. 569). He has a strong antipathy to Conscience, who has striven to keep Manhode on the right way. When his true identity is actually revealed, Manhode is tempted to go against the teaching of Conscience, and he is most appreciative when Folye gives him a new name - Shame. This summative naming is a turning point in the action, and it signifies that Manhode has found a new evil identity and lost his old one. Conscience is immediately brought back on stage, and he sets about recovering lost ground.

These examples of evil fools in the English moralities may be supplemented by the industry of Fansy and Foly, who play a large part in the downfall of the eponymous hero in John Skelton's Magnyfycence. There the antics of these complementary characters are instrumental in deceiving their victim into losing his kingly qualities and becoming irrational and incompetent. The process is pointed towards exaggerating his confusion about the significance of his own name and nature. Once again they indulge in playing with names. This inheritance of the wickedness of folly on the stage is something of great moment in Shakespeare's drama. His fools are no strangers to mischief, and yet, as we shall recall, they are placed in an ambiguous position because of their unnerving perceptions of truth, and their detailed but disturbing commentary upon human follies. Paradoxically Shakespeare attached wisdom to folly but this is hardly the case in the moralities where the figures of folly show that Man is foolish enough to be an easy victim.

Two other devices create pictures of Man's vulnerability. One comprises the images of his destruction, and the other, perhaps an extension of the failures of the flesh, implies that he is close to animals : that indeed he is no more than a beast. We have seen that in Castle of Perseverance the death of Humanum Genus is presented as stark and grim. In the Banns, the Secundus Vexillator gives the warning of his fate :

Every man in himself forsooth he may it find : 
Whou Mankynde into this werld born is ful bare

And bare schal beryd be at hys last ende. (1. 15-17)

[How

Ever present, the Bad Angel works for the evil destiny :

He is about in euery degre

To drawe me to tho dewylys wode

That in helle ben thycke. (1. 307-9)

[mad devils

Later Largitas links death, impermanence, and the persistent theme of avarice :

Mankynd seyth he hath neuere inowe

Tyl hys mowthe be ful of clay.

Whane he is closyd in dethis dow

What helpyt ryches or gret array? (1. 2637-40)

Avarice, one of the Deadly Sins, is the most important in this play. Significantly he has his own scaffold to which Man eventually is enticed.

Likewise in L'Omme Pecheur La Mort gives a terrible picture of the inevitability of the body's decay and of his power:

De lomme fais ce que ie veulx

en tout temps mon subget se rend. (mii)

An earlier stage direction encapsulates how the dramatist visualised the encounter between Le Pecheur and his companions and the warning sent by God :

Adonc en alant par le gieu ilz [Le Pecheur, Luxure and Finete] chanteront une chanson a plaisance. Et puis apres ilz rencontreront maladie et la mort en leur chemin qui viendront contre lomme. Et dira maladie ce qui sensuit en frappant lomme de ses verges execrablement. Et notez que a ce coup lomme cherra a terre. (mi)

As Le Pecheur appeals for mercy at the later approach of Mort, he «records» in anaphoric speech his predicament at the behest of many destructive forces :

ie recorde que la mort me vient querre 
ie ne scay quant, pour me tollir la vie (aiiii ${ }^{\mathrm{v}}$, p. 408)

It is Castitas in Perseverance, who describes Humanum Genus as no better than a beast (1.2615). This is said in the context that it is only with the coming of death that the sinfulness will end. Anima, in Wisdom, is betrayed by Lucifer, and in a dramatic sequence she appears lamenting her disfigurement :

Here Anima apperythe in the most horrybull wyse, fowlere than a fende. (1. 902sd)

A moment later seven small boys, in the likeness of devils, run out from under her «horrybyll mantyll» (1.912sd). These images of Man as spoiled need to be considered alongside those giving him an admirable nature, and showing him rejoicing in his beauty and attractiveness, as he does in The World and the Child (1. 132-4).

Even though these multiple images in the medieval plays cannot be reconciled with one another to give a fully integrated picture of Man, they do show that in many respects both words and other semiotic systems (movement, action, individual moments, scenic iconography) were made to represent Man as a dynamic figure in the search for salvation. Though the authors of morality plays pointed their material towards didactic ends, the variety of emotions which their images embraced was potent and memorable. The desire to celebrate the quasi-divine beauty of Man in a beautiful created world may have been emphasised for didactic purposes, but these images are also a response to direct experience of the deceptiveness of transitory life, the difficulty of achieving lasting happiness, the threat of disaster and annihilation, and human fallibility. The intensity of the images of adversity is controlled by the urge to reconcile suffering with an appreciation of divine order, and subordinated to overall concerns which create the aesthetic of the morality play. However, they generated a potent dramatic medium which could be exploited by Shakespeare, who, I suggest, himself became deeply interested in creating and contemplating a conflicting and paradoxical imagery of Man.

As I have hinted, my transition to Shakespeare's plays incorporates a leap into a new and different kind of theatrical culture. Yet his plays are still plays and they do in part depend upon theatrical images of Man, and, like the moralities, they work by means of both verbal and non-verbal 
semiotics. Even though we may be used to seeing Shakespeare's plays in the theatre (more frequently indeed than we see moralities) yet the way in which visual imagery is incorporated in them is not commonly addressed in critical writings. We may, however, recall how important to us in the theatre are the visual impact of Richard II sitting upon the ground to tell sad stories of the death of kings, of his play with his own hand and that of Bolingbroke as the crown is exchanged. Hamlet points, with an urgent passion, to the contrasting pictures of his father and Claudius, and he leaps into Ophelia's grave; Lear wanders on the heath with a Fool and a pretended madman, blind Gloucester and mad Lear recognise one another, Lear carries in the body of Cordelia. These iconic moments - and there are many more - mean that Shakespeare saw with his imagination and made much of such incidents. Such visual images could be, and indeed often were, enhanced by marvellously apposite language :

Be buried quick with her, and so will I!

(Hamlet, V.1.264)

I see it feelingly.

(King Lear, IV.6.145)

But our seeing is still indispensable. Even with a radio production we can still «see» with our mind's eye.

The transition is, however, from one kind of theatre to another, even though there may be much continuity. For all the ideological, philosophical and political material in Shakespeare's plays there is also a commercial principle. He was entertaining for money, and his plays had to be successful within the practicalities of the new businesslike professional theatre generated by James Burbage. If they taught the audience about themselves, their didacticism was incidental, whereas the morality plays set out to teach the way to heaven, and used «entertainment» as a means. The principle must be that the older plays were organised according to didactic ends and everything - including the images of Man we have been considering - functioned within this objective. This does not imply that they were necessarily less theatrical, but it does mean that the images of man were consonant with and embodied broader theological objectives. However, I don't think it will quite do to assume that these are entirely different, for «theology» like «entertainment», in the senses I am using these words, both imply the inclusion of a variety of experiences and 
emotions, and it is perhaps here that we may come upon common ground between the two theatrical modes.

Nevertheless it is worth pursuing a little further what the absence of an overarching didactic intention may mean. Characters are organised differently by Shakespeare since they have to function as part of a dramatic context rather than as part of an essentially moral structure. Here the selfreflection which they exhibit is part of an interest in inducing us to see them as coherent, or at least as a mixture of a variety of traits. I want to add, quickly, that I don't think that Shakespeare always wanted to make his characters realistically integrated into three-dimensional beings, any more than he always sought probability in his plots. But he was interested, I submit, in putting together, in collocating different and sometimes paradoxical aspects within his human figures. Sometimes he also retains a sense that his characters are emblematic or representational of others, a practice which echoes the typological conventions of the morality play creators of mankind. This latter device seems to me to be particularly developed in King Lear.

The continuity of Christian culture, in spite of the changes of emphasis embodied in the Renaissance and the Reformation, also informs Shakespeare's work in general. Of the three plays considered here, Richard II is notable for Richard's repeated identification of himself with Christ, and his opponents with Judas. Hamlet presents us with a considerable accumulation of religious culture, such as the notion of old Hamlet in Purgatory, the problem of Claudius' persistence in sin, and the issue of the burial of a suicide. I doubt whether Shakespeare's exploitation of these for dramatic purposes is casual. Though there are several references to gods in King Lear and their reaction to human affairs, especially for disaster and evil behaviour, Christian assumptions underly the paganism, even if the ultimate view is not Christian.

One of the strongest differences between the moralities and the Shakespeare plays turns, I believe, on the difference in the attitude to the plot. Instead of the dominance of the moral-didactic enterprise in the former, Shakespeare's plots work partly because there is usually an interest in how they will unfold, even when he confounds or even defies expectation, or when he deliberately makes a plot difficult to unravel (in both comedy and tragedy). It is striking that a great deal of criticism has been deeply concerned with questions of probability or appropriateness, especially in connection with the endings. The images of Man Shakespeare employs are closely linked to the directions and crosscurrents which are established in the momentum of the plotting. The narrative of Richard II shows his fall, and the ending is important and commands 
attention, but during the process we are persistently shown two Richards (at least !). One is the self-glorifying king: «We were not born to sue, but to command» ${ }^{3}$; the other is the man wearing the robes who is afflicted, self-reflecting and self-pitying. Thus the use made of images of Man in this play tends to be frequently associated with the links and the distancing between individual and monarch, comprehensively exposed by the plot. The characterisation of Hamlet himself is much more complex. Within this complexity, however, one may perceive that there is a persistent interest in Fate, and in Hamlet's own sense that he is caught in a situation and given a role from which he would rather escape than be imprisoned by it : «O cursèd spite, / That ever I was born to set it right !» (I.5.189-90). This feeling occurs again later in the play. As for Lear, we may note that he too is preoccupied with his role as a King, but the working out of the plot puts him in positions where his own powerful feelings induce a despairing search for the nature of kingship and also for his own identity. Arnold Kettle observes : «His story, put in its simplest terms, is the story of his progress from being a king to being a man, neither more nor less» ${ }^{4}$. One could say that this is somewhat like the predicament of King Richard, but in doing so one is immediately struck by the differences in their attitudes to themselves and their relationships with others.

In considering Shakespeare's use of the images of Man I should like to arrange them thematically, since I believe that in doing so one may perceive a number of correspondences. Broadly these are grouped under

\author{
fortune, \\ individuality, \\ the ages of man, including death, \\ and some of the antagonists.
}

Fortune itself is primarily an ancient topos but we have seen that Man's subordination to it shows itself in his vulnerability to disaster and his own weakness in the moralities. Shakespeare was often interested in it in terms of plot, as well as in using it as a recurrent motif. In Richard II much is made of the circumstance of Richard's return from Ireland one day too late to receive the support of his Welsh army. Here, and in Hamlet's «fortunate» encounter with the pirates, such events are seen as turning points, but the circumstances of the ensuing destructions are not presented as though they depend entirely upon fortune for their effectiveness. Nor are these turns of events much dwelt upon, as they are chiefly used to set up 
the situations and emotions which follow from them. They are triggers for subsequent events which themselves are part of a broader dramatic texture.

In Hamlet some of the sense of Man's subjection to Fortune comes in the play-within-the-play where the impression of human impermanence is voiced by the Player King :

Our wills and fates do so contrary run

That our devices still are overthrown :

Our thoughts are ours, their ends none of our own.

(III.2.193-5)

This is especially ironic since it is part of a court entertainment which, one may assume, incorporates contemporary expectations. Hamlet's reaction to his own circumstances turns upon his own desire for release. He praises Horatio's stoical distancing: he is not passion's slave and Hamlet consequently approves those who «are not a pipe for Fortune's finger / To sound what stop she please» (III.2.63-4). The sentiment is sharpened later in the same scene where he attacks Rosencrantz and Guildenstern for trying to play upon him like a pipe (III.2.335-41). In this reply Hamlet is also concerned with his own identity : «Call me what instrument you will, though you can fret me, you cannot play upon me» (III.2.340-1). We note, however, that this discourse about fortune occurs in the context of Hamlet's fears that he is being deceived by Claudius and his two former fellow students. The sense of the obligation placed upon him by circumstances also has a moral force. He sees himself as having to act as a corrective of the faults of others echoing the sense of being trapped as noted earlier :

But heaven hath pleased it so To punish me with this, and this with me, That I must be their scourge and minister.

(III.4.157-9)

In King Lear the sense that Man is subordinated to forces aligned to Fortune, or misfortune, is articulated by a number of characters. This in itself is a timely reminder that the images of Man are not solely a matter of the nature and function of the protagonist: they are in fact diffused throughout this play and it is no exaggeration to say that the discourse of fate is one of its abiding features. It is also significant that formulations about Man's subjection to Fortune are spoken in character, so that they 
have to be seen in a continually changing perspective. This dynamism is partly determined by the needs of the plot - or rather the contrasting views are themselves incorporated within the plot, and they function in complement with it. For example, Edmund comments tartly upon his father's attribution of the disasters of the time to planetary influence : «As if we were villains by necessity ; fools by heavenly compulsion... and all that we are evil in by a divine thrusting on» (I.2.112-6). The use of «heavenly» and «divine» sharpens the irony, and the passage points ahead to the strife, which is to come between this son and father.

In a later, concentrated series of speeches, the sense of man's submission to Fortune is carried further by Edgar and Gloucester. This sets up a contrast with Edmund's bitter judgement, which in itself still has the ring of truth. Edgar begins even before he meets his blinded father :

The lowest and most dejected thing of fortune, Stands still in esperance, lives not in fear.

When he does see Gloucester a moment later, he has to try to find some way of confronting the misfortune :

World, world, O world !

But that thy strange mutations make us hate thee, Life would not yield to age.

(IV.1.10-2)

As this terrible scene is played out, the audience is subjected to the effects of the dramatic irony in knowing who Gloucester is and what has happened to him, and, in being made aware that Gloucester cannot see Edgar. The picture of Man's submission to fate is intensified by Edgar: «the worst is not / So long as we can say "This is the worst"» (IV.1.2930). The discourse reaches a climax in Gloucester's despair :

As flies to wanton boys are we to the gods :

They kill us for their sport.

I should add though that there are other aspects of the play which can be set against the discourse of fortune / misfortune. Thus, if the images do 
have much in common with those of the moralities, we can say that in this different context they are here being made to serve a different purpose.

The choric gardener in Richard II notices that the fortunes of King Richard and Bolingbroke «are both weighed» (III.4.85). The conflicts and suffering within Richard himself are exposed through his extensive use of images. In some of these he dwells on his misfortune, though it is notable that the context means that Shakespeare is not limiting the possible significance of what Richard says to simple endorsement. In the deposition scene Richard intensifies his sense of falling, coupled with loss, after he has surrendered the crown :

Made glory base and sovereignty a slave,

Proud majesty a subject, state a peasant.

(IV.1.241-2)

But there is also the wish that he may fall, which is part of the tension in the scene, a state of mind which, perhaps, is necessary since he cannot save himself :

O that I were a mockery king of snow,

Standing before the sun of Bolingbroke,

To melt myself away in water-drops !

(IV.1.250-2)

In Act Five he accepts inevitability as he parts from the Queen :

I am sworn brother, sweet,

To grim necessity, and he and I

Will keep a league till death.

In the scene of his death there is both foreboding and a need to express a submission to it :

But whate'er I be,

Nor I, nor any man that but man is,

With nothing shall be pleased till he be eased

With being nothing. 
Quite apart from the significance of these images for the perception of Richard's character, Shakespeare's use of them may also be linked with their function as conventional tragic concepts, which have both classical and medieval antecedents.

In their struggles to establish or sustain their sense of their own identity, Shakespeare's three protagonists react against the pressures of circumstance. As he faces the possibility of losing his crown, Richard turns towards his own common humanity :

I live with bread, like you ; feel want, Taste grief, need friends.

But it is in the deposition scene where the close interrelationship between Richard's sense of himself as a king, now without power, and the loss of his personal integrity receives its most powerful expression. He seeks to retain the latter by at least remaining king of his own griefs, and he exclaims against Northumberland's urging him to read the list of his offences. Losing his title is closely associated with losing his own name, and this may well recall the terrible predicament of the dying Humanum Genus in Castle of Perseverance, also aware of losing all. Richard says :

I have no name, no title, No, not that name was given me at the font, 4 But 'tis usurped. Alack the heavy day That I have worn so many winters out And know not now what name to call myself.

This is followed by Richard's extended play with the idea of his «face» as he searches his image in the glass. The scene has an intense visual dimension as he lets the mirror fall and break, and Richard's mention of the «silent king» who is watching him enriches this.

Hamlet's great variety of emotions is expressed through a number of images. Even though his madness may be pretended, he expresses deep despair :

You cannot, sir, take from me anything that I will more willingly part withal - except my life, my life, my life. 
Aware of the power of his feelings and yet unable to restrain them, he enters a storm of self-criticism later in the same scene :

What would he do?

Had he the motive and the cue for passion

That I have? (537-9)

[...] for it cannot be

But I am pigeon-livered and lack gall

To make oppression bitter, or ere this

I should a fatted all the region kites

With this slave's offal. (553-7)

Ay, sure, this is most brave

That I, the son of the dear father murderèd

Prompted to my revenge by heaven and hell,

Must, like a whore, unpack my heart with words

And fall a-cursing like a very drab,

A scullion! (560-5)

Lear's troubles, as we have noted, show him moving from concern about his state as a king to a sharper perception of his own nature. It is a grim discovery, but in the rather black and white world of this play, there does seem to be a concern to explore the basic, irreducible essence of Man. Some of the images call upon the parallel with beasts, an idea set up by Edgar's remark as he contemplates his disguise :

and am bethought

To take the basest and most poorest shape

That ever penury, in contempt of man, Brought near to beast.

This topos of Man as beast is also classical, and is found in Ovid, for example (Taylor, p. 66-80).

As the storm develops Lear perceives himself as «A poor, infirm, weak, and despised old man» (III.2.19), but the climax in this reduction to essentials comes in his juxtaposition with Poor Tom. Again there is the link with the beasts, but this time in the highly charged visual context we have already noticed, Lear's way of describing himself is accompanied by his taking off his clothes : 
Why, thou wert better in thy grave than to answer with thy uncovered body this extremity of the skies. Is man no more than this? Consider him well. Thou owest the worm no silk, the beast no hide, the sheep no wool, the cat no perfume. Ha! Here's three on's are sophisticated! Thou art the thing itself; unaccommodated man is no more but such a poor, bare, forked animal as thou art. Off, off, you lendings!

This action may very well be a development of the naked man who appears at the beginning of the morality plays, but it is also possible that the spiritual desolation embodied in this speech, recalls, for a Christian audience, the utter destruction of Man, as in The Castle of Perseverance at the point of death. Again we should notice that for all its powerful language this episode has a compelling visual aspect as Lear struggles to remove his clothes. The imagery used by Lear later in the play continues to show impressions of man reduced to simple but pitiful levels. I take the view that Lear becomes increasingly pitiful as the end approaches, even though there are nowadays readings of the play, making him less deserving of sympathy. When he awakes from the healing sleep, he says to Cordelia :

I am a very foolish fond old man,

Fourscore and upward, not an hour more nor less.

(IV.7.61-2)

This suggests that he has at length learned something about himself. Lurking behind it is the now silent pride of the earlier scenes. So that whilst there is an emphatic emotional charge here, there is also an underlying moral dimension which may well have affinities with the morality plays. But we should recall the earlier point that such moral aspects are no longer dominant as in the moralities : instead there is the relentless insistence on the force of the plot, and its power which is practically that of a myth. This includes the pressure of narrative.

The images of the ages of Man are strongest in King Lear where his own advanced years are an integral part of his tragic predicament. Edgar, whose part carries so much commentary, advises that : 
Men must endure

Their going hence, even as their coming hither.

(V.2.9-10)

Although Lear's own references to the sufferings of age are manifold, and replicated by Gloucester, he also speaks of birth. It is striking that this reference is also interwoven with the image of the ubiquity of folly, one of the dominant themes of the play. Indeed the close interaction of different strands of the imagery of Man is one of the special features of this play. Speaking to the blinded Gloucester, Lear says :

Thou must be patient. We came crying hither;

Thou know'st, the first time that we smell the air, We wail and cry.

(IV.6.172-4)

It is noted in the Cambridge edition that this last image has affinities with scripture, and Montaigne, via Florio's translation, and also that Tilley found it to be proverbial ${ }^{5}$. Lear adds a kind of gloss of his own to what he has said, introducing the idea of folly:

When we are born, we cry that we are come

To this great stage of fools.

(IV.6.176-7)

The ambivalence of folly in the play forms another important topos. In part folly is seen as one of the enemies of Man's state following the medieval tradition, as this last quotation suggests. But by now Lear's Fool has been removed from our attention, and it really is quite difficult to recall him. Nevertheless he had embodied wisdom in his folly, and given many pointed and bitter images of Man as a fool. Though his main function was no doubt to expose Lear's own folly in overlooking Cordelia and giving all to his other two daughters, and to make Lear think again, Shakespeare's dramatic technique in separating him from others by his songs and by his own characteristic forms of expression have given him a peculiar force. Indeed it is one of the abiding performance interests of the play to see how directors set about giving a visual dimension to this strange and searching voice. He relentlessly exposes Lear's mistakes and he evokes for Lear a series of images, closely related to the ones we have been discussing, which actually make Lear appear even less than a fool. 
The images come in quick succession. Of the «sweet and bitter fool» he says :

The one in motley here,

The other found out there.

This followed by :

That such a king should play bo-peep

And go the fools among. (1. 154-5)

I am a fool, thou art nothing. (1. 169)

That's a shealed peascod. (1. 174)

Lear's shadow. (1. 206)

This is not the only occasion in King Lear when the images of Man come in concentrated succession and it seems plain that this technique of accumulation is quite deliberate. The technique is all the stronger because the images come through many voices, and in different contexts, showing us that the dramatic techniques for using them are highly sophisticated.

The three plays give a very complex picture of the corruption and depravity of Man. But because everything that is said is said by an observing voice there is always the possibility that the judgements are themselves subject to evaluation. Nevertheless Edgar, as Poor Tom, gives a fantastic picture of selfish and sinful indulgence. Though he does not mention all seven of the Deadly Sins, it seems as though they are in mind, and the dehumanised picture is powerful. Indeed the speech does turn into one of those allegorical phases which are intensified by the descent into imagery reducing man to an animal :

A serving-man, proud in heart and mind; that curled my hair; wore gloves in my cap, served the lust of my mistress' heart, and did the act of darkness with her ; swore as many oaths as I spake words, and broke them in the sweet face of heaven : one that slept in the contriving of lust, and waked to do it.

(III.4.80-4) 
[...] hog in sloth, fox in stealth, wolf in greediness, dog in madness, lion in prey.

(III.4.86-7)

This speech is part of the dialogue during the storm scene when there is an overwhelming force towards exposure of Man's sinfulness and vulnerability. Hamlet's rhetoric to Ophelia gives a picture of the depravity of his thoughts and creates a demeaning picture :

I am very proud, revengeful, ambitious, with more offences at my beck than I have thoughts to put them it, imagination to give them shape, time to act them in. What should fellows as I do crawling between heaven and earth ?

(III.1.125-8)

Yet Shakespeare could also make use of a sense of the glory of Man. Comparing the portrait of Claudius, the «mildewed ear» with that of his father, Hamlet speaks of :

A combination and a form indeed

Where every god did seem to set his seal

To give the world assurance of a man.

(III.4.59-61)

In the following passage Hamlet's version of the image of divinity found by medieval writers in Man is perhaps crossed with a more humanistic Renaissance aspiration. But the dramatic point of Hamlet's growing climax of images is that what he is about is to reject them. For him, at least, there is no delight :

What a piece of work is a man! How noble in reason, how infinite in faculty, in form and moving how express and admirable, in action how like an angel, in apprehension how like a god - the beauty of the world, the paragon of animals! And yet to me what is this quintessence of dust? Man delights not me... 
Even here the ideas of man as an animal, and his being made out of earth appear, and so too does the concept of Man as godlike.

The images of Man, then, are used in these plays as a reduction of the complexity of experience, as a kind of deliberate oversimplification. The reduction is a way of concentrating and intensifying some aspects of the subject of Man. There is a distinct possibility that some of these were conventions. For medieval writers, working in a didactic genre, it was intensely helpful to have a way of representing essential versions of man, for there was a dramatic force in making things as distinctive as possible. In Shakespeare's later stage development, however, the process of reduction is integrated with other aesthetic and dramatic functions into each individual play's context. The development of a new style of drama, together with the mechanics of professional production in the context of the newly evolved London theatre, made these images, which must have been commonplaces partly because of the continuity of Christian culture, a rich resource. Through them the newly evolving Renaissance world had a means of addressing the state of Man's life. Shakespeare's plays, even on the rather limited evidence adduced here, are not morality plays, yet there is much in these images which suggest both common ground and continuity. Fortunately it is not my task here to elaborate the ways in which his work differed from that of his predecessors. Even more fortunately, I feel I can leave the study of such elaborations to the work of others in this Society.

Peter HAPPÉ

University of Southampton

\section{NOTES}

' For editions see Bibliography.

${ }^{2}$ For a possible doubling scheme see Davidson and Happé (1999), p. 117 .

${ }^{3}$ I.1.196. Ironically, Richard immediately observes that his command is ignored.

${ }^{4}$ See Martin and Owens, p. 251. Kettle discusses Hamlet in terms of Renaissance humanism, p. 60. 
s J.L. Halio (ed.), The Tragedy of King Lear, Cambridge, Cambridge University Press, 1992, p. 227.

Texts

\section{Bibliography}

L'Omme Pecheur in Moralités françaises, ed. W. Helmich, 3 vols, Geneva, Slatkine, 1980, vol. 1, p. 111-420.

The Macro Plays, ed. M. Eccles, EETS 262, London, Oxford University Press, 1969, for Castle of Perseverance, Wisdom, and Mankind.

Magnyfycence by John Skelton in Four Morality Plays ed. Peter Happé, Harmondsworth, Penguin, 1979.

The Norton Shakespeare, ed. S.Greenblatt, W. Cohen, J.E. Howard, and K.E. Maus, New York, Norton, 1997.

The World and the Child, ed. Clifford Davidson and Peter Happé, Kalamazoo, Medieval Institute Publications, 1999.

Books and Articles

HAPPE, Peter, «Staging L'Omme Pecheur and The Castle of Perseverance», Comparative Drama, n³0, 1996, p. 377-94.

HeLMICH, Werner, Die Allegorie im französischen Theater des 15. und 16. Jahrhunderts, Tübingen, Niemayer, 1976.

—, «La Moralité : genre à redécouvrir», in Muller, p. 205-338.

KETTLE, Arnold, Literature and Liberation: Selected Essays, ed. G. Martin and W.R. Owens, Manchester, Manchester University Press, 1988.

KNIGHT, Alan E., «La Farce et la moralité : deux genres distincts», in Muller, p. 239-61.

-, Aspects of Genre in Late Medieval French Drama, Manchester, Manchester University Press, 1983.

MULLER, Gari R. (ed.), Le théâtre au moyen age, Quebec, l'Aurore, 1981.

TAYLOR, A.B., "Animals in "manly shape as too outward showe": moralizing and metamorphosis in Titus Andronicus», in his (ed.) Shakespeare's Ovid, Cambridge, Cambridge University Press, 2000, p. 6680 . 